\title{
Lake-sediment record of PAH, mercury, and fly-ash particle deposition near coal-fired power plants in Central Alberta, Canada ${ }^{\text {is }}$
}

\author{
Benjamin D. Barst ${ }^{\mathrm{a}, 1}$, Jason M.E. Ahad ${ }^{\mathrm{b},}{ }^{*}$, Neil L. Rose ${ }^{\mathrm{c}}$, Josué J. Jautzy ${ }^{\mathrm{d}}$, \\ Paul E. Drevnick ${ }^{\mathrm{e}}$, Paul R. Gammon ${ }^{\mathrm{f}}$, Hamed Sanei ${ }^{\mathrm{g}}$, Martine M. Savard ${ }^{\mathrm{b}}$ \\ a INRS-ETE, Université du Québec, 490 de la Couronne, Québec, QC G1K 9A9, Canada \\ ${ }^{\mathrm{b}}$ Geological Survey of Canada, Natural Resources Canada, 490 de la Couronne, Québec, QC G1K 9A9, Canada \\ ${ }^{\mathrm{c}}$ Environmental Change Research Centre, Department of Geography, University College London, Gower Street, London WC1E 6BT, UK \\ ${ }^{\mathrm{d}}$ University of Ottawa, Department of Earth and Environmental Sciences, 25 Templeton St., Ottawa, ON K1N 6N5, Canada \\ e Environmental Monitoring and Science Division, Alberta Environment and Parks, Calgary AB T2E 7L7, Canada \\ ${ }^{\mathrm{f}}$ Geological Survey of Canada, Natural Resources Canada, 601 Booth Street, Ottawa, ON K1A OE8, Canada \\ ${ }^{g}$ Geological Survey of Canada, Natural Resources Canada, 3303-33rd Street N.W., Calgary, AB T2L 2A7, Canada
}

\section{A R T I C L E I N F O}

\section{Article history:}

Received 20 February 2017

Received in revised form

10 July 2017

Accepted 9 August 2017

\section{Keywords:}

Polycyclic aromatic hydrocarbons Mercury

Spheroidal carbonaceous particles

Lake sediments

Stable isotope ratios

\begin{abstract}
A B S T R A C T
We report a historical record of atmospheric deposition in dated sediment cores from Hasse Lake, ideally located near both currently and previously operational coal-fired power plants in Central Alberta, Canada. Accumulation rates of spheroidal carbonaceous particles (SCPs), an unambiguous marker of hightemperature fossil-fuel combustion, in the early part of the sediment record (pre-1955) compared well with historical emissions from one of North America's earliest coal-fired power plants (Rossdale) located $\sim 43 \mathrm{~km}$ to the east in the city of Edmonton. Accumulation rates in the latter part of the record (post-1955) suggested inputs from the Wabamun region's plants situated $\sim 17-25 \mathrm{~km}$ to the west. Increasing accumulation rates of SCPs, polycyclic aromatic hydrocarbons (PAHs) and $\mathrm{Hg}$ coincided with the previously documented period of peak pollution in the Wabamun region during the late 1960s to early 1970s, although $\mathrm{Hg}$ deposition trends were also similar to those found in western North American lakes not directly affected by point sources. A noticeable reduction in contaminant inputs during the 1970s is attributed in part to technological improvements and stricter emission controls. The over one hundred-year historical record of coal-fired power plant emissions documented in Hasse Lake sediments has provided insight into the impact that both environmental regulations and changes in electricity output have had over time. This information is crucial to assessing the current and future role of coal in the world's energy supply.
\end{abstract}

Crown Copyright $\odot 2017$ Published by Elsevier Ltd. All rights reserved.

\section{Introduction}

Coal-fired power plants are significant sources of contaminants to both terrestrial and aquatic environments. Contaminants released during coal combustion include particulates, nitrogen compounds $\left(\mathrm{NO}_{\mathrm{x}}, \mathrm{NH}_{3}\right)$, trace elements such as mercury $(\mathrm{Hg})$, and organic compounds, including polycyclic aromatic hydrocarbons

\footnotetext{
This paper has been recommended for acceptance by Dr. Harmon Sarah Michele.

* Corresponding author.

E-mail address: jason.ahad@canada.ca (J.M.E. Ahad).

1 Current address: Faculty of Agricultural and Environmental Sciences, McGill University, Montreal, QC, Canada.
}

(PAHs). Atmospheric deposition of $\mathrm{Hg}$ is of concern, because once in aquatic environments $\mathrm{Hg}$ may be transformed to methylmercury, which bioaccumulates and biomagnifies in food webs. Consumption of fish contaminated with methylmercury poses a risk to humans and wildlife (Mergler et al., 2007; Scheuhammer et al., 2007). PAHs are also of concern, as they are toxic to a variety of aquatic species (Colavecchia et al., 2004; Newsted and Giesy, 1987) and many are suspected or known carcinogens (Eisler, 1987; Boffetta et al., 1997; Boström et al., 2002).

The Western Canada Sedimentary Basin contains extensive coal deposits that are mined for power generation. In Edmonton, Alberta, the generation of electricity from coal combustion began in the late 19th century and continued within the city until the 1950s, when the major coal-fired power plant in the city was converted to 
burn natural gas. This was also the period when the first coal-fired power plant was commissioned in the Wabamun region located approximately $60 \mathrm{~km}$ to the west (Fig. 1). In 2014, coal combustion accounted for approximately $55 \%$ or 44,442 gigawatt hours of the electricity generated in Alberta (www.energy.alberta.ca/), much of which was produced by the three currently operational coal-fired power plants (Sundance, Genesee, Keephills) in the Wabamun region (CEC, 2011). A fourth plant (Wabamun Generating Station) was decommissioned in 2010. Collectively, the plants have operated in the area for more than 50 years, yet the extent to which they impact aquatic ecosystems in the region has only garnered interest in the last decade or so.

The three operational plants in the Wabamun region rank among the ten highest emitters of $\mathrm{NO}_{\mathrm{x}}, \mathrm{Hg}$, and particulate matter $\left(\mathrm{PM}_{10}\right)$ in Canada (CEC, 2011), although agricultural emissions are also a major source of $\mathrm{NO}_{\mathrm{x}} / \mathrm{NH}_{3}$ in central Alberta (Schindler et al., 2006). Coal-fired power plants may also be significant sources of trace elements and PAHs. In sediment cores collected from Wabamun Lake (Fig. 1), Donahue et al. (2006) reported a six-fold increase in Hg flux, increases in concentrations of several other trace elements in post-1950 sediments, and 35-fold increases in fluxes of individual PAH compounds since 1850. The enrichments of trace elements and PAHs were less prominent in the sediments of two other lakes (Sainte Anne and Pigeon) more distal to the region's main power plants, suggesting a localized atmospheric influence (Donahue et al., 2006). The geographic extent of contamination by the coal-fired power plants in the Wabamun region was further studied through measurements of trace metals (As, Cd, Co, Cr, Cu, $\mathrm{Hg}, \mathrm{Mo}, \mathrm{Ni}, \mathrm{Pb}, \mathrm{Sb}, \mathrm{V}, \mathrm{W}$, and $\mathrm{Zn}$ ) in sediment cores taken from nine lakes in central Alberta (Sanei et al., 2010). This research documented increased accumulation rates of selected trace elements as well as qualitative physical evidence for atmospherically-deposited spherical particles of siliceous fly-ash in post-1956 sediments from lakes nearest the power plants.

In addition to these inorganic ash spheres, fly-ash emitted in flue gases contains spheroids that are primarily formed of carbon. These particles, known as spheroidal carbonaceous particles (SCPs), are the result of the incomplete combustion of fossil fuels (pulverized coal particles or oil droplets, but not gas). They are not created naturally and are therefore unambiguous markers of hightemperature anthropogenic combustion processes such as electricity generation. Previous studies have compared profiles of SCPs in sediments with the distributions of other contaminants released during fossil-fuel combustion (Martins et al., 2010; Yang et al., 2001); however, this type of quantitative comparison has yet to be applied to dated sediments collected from lakes in the vicinity of historical and modern coal-fired power plants in Alberta.

In the present study, we report a historical record of atmospheric contamination in dated sediment cores from a small lake in Central Alberta located near both current and previously operational coal-fired power plants. Concentrations of SCPs, PAHs and $\mathrm{Hg}$ were measured to evaluate the extent of contamination related to coal-fired power plants in the region, and to assess what impact both environmental regulations and changes in electricity output have had over time. Total organic carbon (TOC), C/N and stable carbon $\left(\delta^{13} \mathrm{C}\right)$ and nitrogen $\left(\delta^{15} \mathrm{~N}\right)$ isotope ratios of organic matter $(\mathrm{OM})$ were determined to further examine anthropogenic inputs and changes in lake productivity over the past century.

\section{Materials and methods}

\subsection{Study area}

Hasse Lake (53²9' 14.0" N Latitude, $114^{\circ} 10^{\prime}$ 23.0” W Longitude; Fig. 1) is located approximately $45 \mathrm{~km}$ west of Edmonton, Alberta. This mesotrophic lake, situated in the boreal mixed-wood biome, covers an area of $0.90 \mathrm{~km}^{2}$, is at an elevation of $729 \mathrm{~m}$ above sea level, and lies adjacent to a provincial park to its northwest. The lake's drainage basin is approximately $7.4 \mathrm{~km}^{2}, 65 \%$ of which has been cleared for agriculture (Mitchell and Prepas, 1990).

The major current and historical electricity generation plants (including coal-fired and natural gas-fired power plants) in proximity to Hasse Lake include two to the east in Edmonton (Rossdale and Clover Bar) and four to the west in the Wabamun region

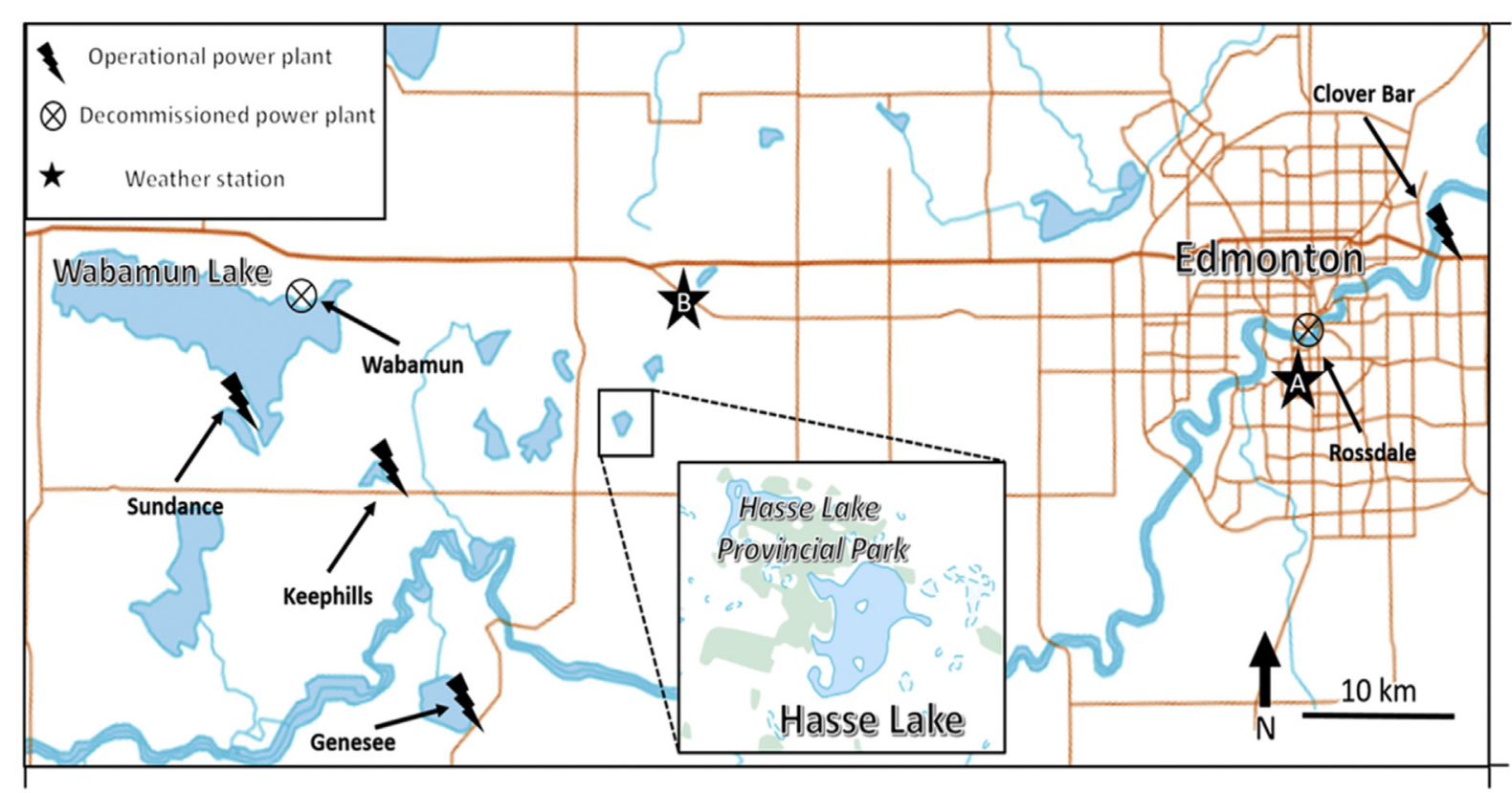

$53^{\circ} 41^{\prime} \mathrm{N}$

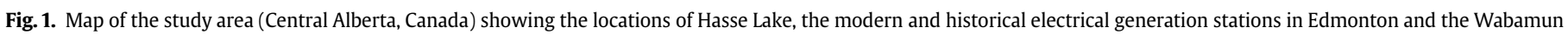
region, and the Edmonton South Campus (A) and Edmonton Stony Plain (B) weather stations. 
(Wabamun, Sundance, Genesee, and Keephills) (Fig. 1). The Rossdale power plant began operations in Edmonton near the beginning of the 20th century and operated until 1998. In the late 1940 s the plant's boilers began to be converted to burn natural gas, rather than coal, and by 1955 this transition was complete. Clover Bar generating station was commissioned in 1970 as a natural gas-fired plant on the eastern edge of Edmonton. The plant was closed in 2005; however, several new gas-fired units were commissioned at the site in 2008 and 2009.

The Wabamun power plant, the first to be opened in the Wabamun region, was commissioned in 1956 and operated on the northeast shore of nearby Wabamun Lake until 2010. The Sundance power plant is located on the southeast shore of Wabamun Lake and was commissioned in 1970. The Keephills power plant is located approximately $7 \mathrm{~km}$ southeast of Wabamun Lake and was opened in 1983. Finally, the Genesee power plant is located approximately $23 \mathrm{~km}$ southeast of Wabamun Lake and was opened in 1989. The three coal-fired power plants currently in operation in the Wabamun region generate a combined output of $3860 \mathrm{MW}$ electricity (TransAlta). A study by Sanei et al. (2010) placed the main deposition area of the four power plants in the Wabamun region approximately $20 \mathrm{~km}$ west of Hasse Lake. Although the predominant wind direction is from the west, easterly winds are not uncommon in the region (Fig. 2).

\subsection{Sampling and geochronology}

Sampling was carried out in October 2012 using an inflatable raft. Gravity cores were collected in the deepest part of the lake at a spacing of approximately $1 \mathrm{~m}$ over a surface area covering around $5 \times 5 \mathrm{~m}$, following a similar protocol used by Jautzy et al. (2013, 2015). For PAH and SCP analyses, seven cores were subsampled at $1 \mathrm{~cm}$ intervals, and all layers from the same depth intervals were pooled together. Two additional cores were collected; one was used to measure $\mathrm{C}$ and $\mathrm{N}$ elemental, stable isotope ratios $\left(\delta^{13} \mathrm{C}, \delta^{15} \mathrm{~N}\right)$, and radioisotopes (for dating, see below). The second core was used to measure total $\mathrm{Hg}$. Sediments were freeze-dried prior to all analyses. To evaluate the accuracy of comparing different parameters in aligned cores, an additional set of $\delta^{13} \mathrm{C}$ and $\delta^{15} \mathrm{~N}$ data was determined in the same core that was used to measure $\mathrm{Hg}$.

Dried sediment samples were analyzed for ${ }^{210} \mathrm{~Pb},{ }^{226} \mathrm{Ra},{ }^{137} \mathrm{Cs}$ and ${ }^{241} \mathrm{Am}$ by direct gamma using an ORTEC HPGe Well Detector (Oak Ridge, TN, USA) series well-type coaxial low background intrinsic germanium detector. Lead-210 was determined via its gamma emissions at $46.5 \mathrm{keV}$, and ${ }^{226} \mathrm{Ra}$ by the $295 \mathrm{keV}$ and $352 \mathrm{keV}$ gamma rays emitted by its daughter isotope ${ }^{214} \mathrm{~Pb}$ following 4 weeks storage in sealed containers to allow radioactive equilibration. Cesium-137 and ${ }^{241} \mathrm{Am}$ were measured by their emissions at $662 \mathrm{kev}$ and $59.5 \mathrm{kev}$ (Appleby et al., 1986). The absolute efficiencies of the detector were determined using calibrated sources and sediment samples of known activity. Corrections were made for the effect of self-absorption of low energy gamma rays within the sample (Appleby et al., 1992). The resulting data were used to determine sediment dates and sediment accumulation rates with the constant rate of supply (CRS) model (Appleby and Oldfield, 1978). The analysis of ${ }^{210} \mathrm{~Pb}$ and ${ }^{226} \mathrm{Ra}$ allowed for the determination of unsupported (or excess) ${ }^{210} \mathrm{~Pb}\left({ }^{210} \mathrm{~Pb}\right.$ minus ${ }^{226} \mathrm{Ra}$ ) and supported (or background) ${ }^{210} \mathrm{~Pb}\left({ }^{210} \mathrm{~Pb}\right.$ and ${ }^{226} \mathrm{Ra}$ are in equilibrium) for the CRS model. The artificially produced radionuclide ${ }^{137} \mathrm{Cs}$, which has an expected peak of 1963, in association with nuclear weapons testing, was also analyzed, for validation of the ${ }^{210} \mathrm{~Pb}$ chronology.

\subsection{SCP extraction, identification, and quantification}

The extraction and quantification of SCPs in Hasse sediments were carried out according to Rose (1994). Briefly, the removal of unwanted sediment fractions (organic, carbonate, and siliceous materials), from the subsampled core sections, was facilitated by selective chemical attack with strong acids. Known portions of the final residues were then evaporated onto cover-slips, before mounting onto microscope slides. Particles were counted using a light microscope at 400x magnification. SCP identification was based on the criteria presented in Rose (2008). The percentage of the final suspension evaporated on each coverslip and the number of SCPs per coverslip were used to calculate the number of SCPs per gram dry weight of sediment $\left(\mathrm{g} \mathrm{DW}^{-1}\right)$. The concentrations of SCPS in each interval were multiplied by the interval's sediment

\section{A) Edmonton South Campus}

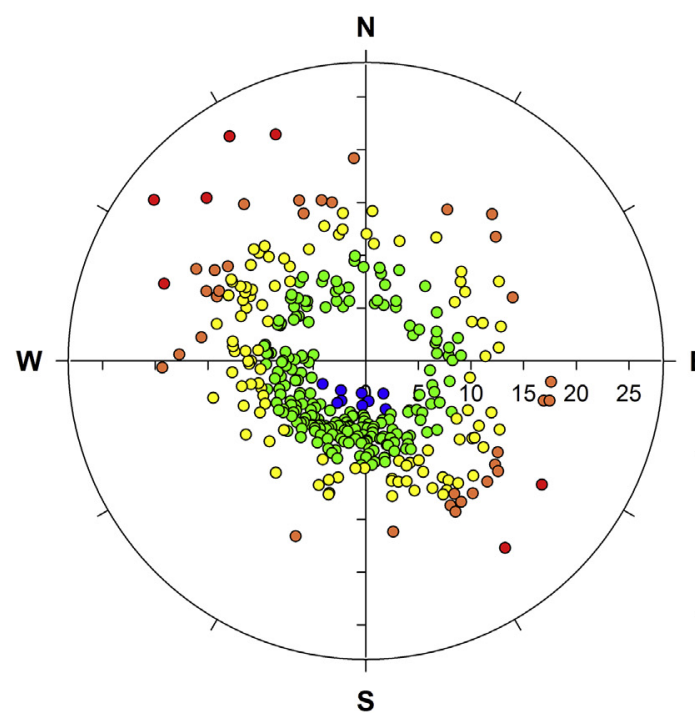

\section{B) Edmonton Stony Plain}

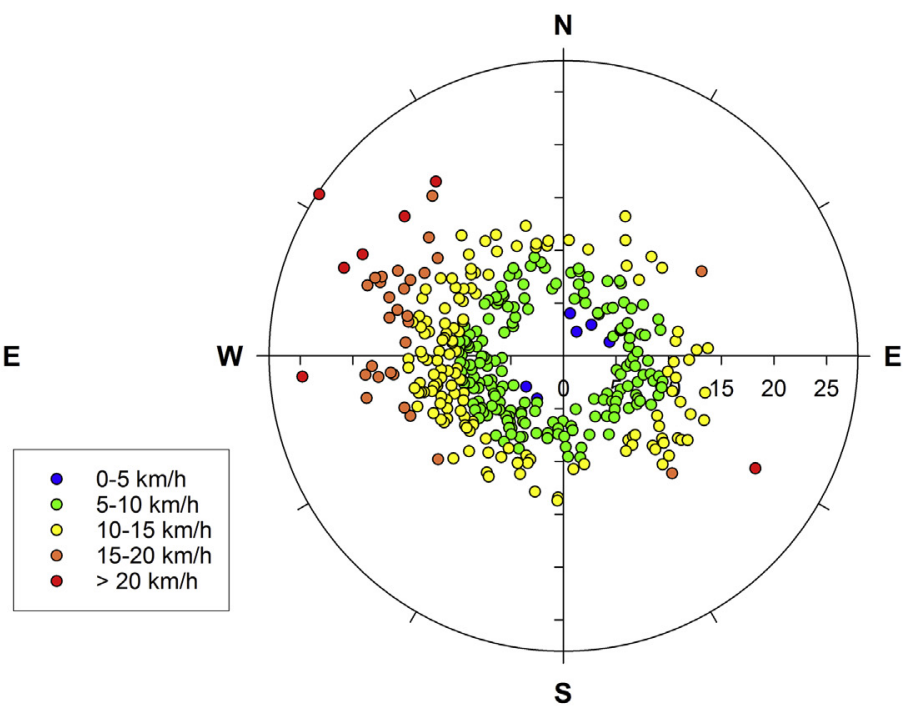

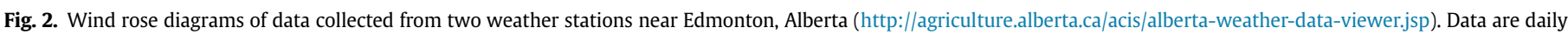
averages collected at Edmonton South Campus (A) and Edmonton Stony Plain (B) during 2015. The locations of the weather stations are shown on Fig. 1. 
accumulation rate to calculate SCP accumulation rates (Rose, 1994). Analytical blanks and SCP reference material (Rose, 2008) were included with all sample digestions. Measured SCP concentrations were within $10 \%$ of the accepted reference concentration. The detection limit for the technique is typically less than $150 \mathrm{~g} \mathrm{DW}^{-1}$ and calculated concentrations generally have an accuracy of c. \pm 45 $\mathrm{g} \mathrm{DW}^{-1}$.

\subsection{Total organic carbon, nitrogen, and sediment stable isotopes}

The percentages and $\delta^{13} \mathrm{C}$ ratios of total organic carbon (TOC) in homogenized sediment samples decarbonated with $6.4 \% \mathrm{H}_{2} \mathrm{SO}_{3}$ were determined using an elemental analyzer (Carlo Erba NC 2500, CE Instruments, Milan, Italy) coupled to a PRISM-III IRMS (Fisons Instruments, Middlewich, UK). The total nitrogen contents in homogenized sediment samples were determined using an elemental analyzer (Costech 4010, Costech Analytical Technologies, Valencia, CA) coupled to a Delta V IRMS (Thermo-Electron Corporation, Bremen, Germany). Compositions ( $\mathrm{C}$ and $\mathrm{N}$ ) and isotope ratios $\left(\delta^{13} \mathrm{C}\right.$ and $\delta^{15} \mathrm{~N}$ ) were calibrated against a range of international standards (NSB-19, LSVEC, IAEA-N1, IAEA-N2 and USGS-25), reference materials (Low Organic Content Soil Standard OAS, High Organic Sediment OAS, Birch Leaf, Algae, Olive Stone, Coconut Shell) and inhouse standards (vanillin and $\left.\left(\mathrm{NH}_{4}\right)_{2} \mathrm{SO}_{4}\right)$ obtained from Elemental Microanalysis Ltd. (Okehampton, UK). Based on replicate measurements of the same sample, the analytical uncertainties for $\mathrm{C}$ and $\mathrm{N}$ compositions and $\delta^{13} \mathrm{C}$ and $\delta^{15} \mathrm{~N}$ ratios were better than $0.3 \%, 0.04 \%, 0.3 \%$ and $0.4 \%$, respectively.

\subsection{Analysis of PAHs}

The extraction and quantification of PAHs followed the procedure presented in Jautzy et al. (2013). Briefly, lyophilized sediment samples and method blanks were spiked with a known amount of $m$-terphenyl as a surrogate standard prior to microwave extraction (Microwave Accelerated Reaction System, MARS; CEM Corp., Matthews, NC, USA) with 1:1 acetone/hexane. The samples were then filtered with a solvent rinsed glass fiber filter prior to saponification with a $0.5 \mathrm{M}$ methanolic $\mathrm{KOH}$ solution. The saponified samples were liquid-liquid extracted with hexane and activated copper was added to remove elemental sulfur. The extracts were then separated into two fractions (F1, hexane; F2 hexane/ dichloromethane) using a glass chromatographic column packed with fully activated (pre-combusted at $450{ }^{\circ} \mathrm{C}$ for $4 \mathrm{~h}$ ) silica (70-230 mesh, Silicycle, Québec, Canada) and a small layer of anhydrous sodium sulfate to remove any residual water.

The F2 fractions containing PAHs were evaporated to $1 \mathrm{ml}$ and spiked with $o$-terphenyl as an internal standard before quantification with an Agilent Technologies (Santa Clara, CA, USA) gas chromatograph mass spectrometer (GC-MS) system (MSD 5975C and GC 7890A; Agilent Technologies) equipped with an Agilent J\&W DB-5 column $(30 \mathrm{~m} \times 0.25 \mathrm{~mm} \times 0.25 \mu \mathrm{m})$ in selected ion monitoring (SIM) mode. Concentrations of parent PAHs were determined using external standards, while concentrations of alkylated PAHs were determined using the closest external standard available and identified with at least two different ions. The following GC temperature program was applied: $70{ }^{\circ} \mathrm{C}$ (hold $2 \mathrm{~min}$ ), increase to $290^{\circ} \mathrm{C}$ at a rate of $8^{\circ} \mathrm{C} / \mathrm{min}$ (hold $8 \mathrm{~min}$ ), and increase to $310^{\circ} \mathrm{C}$ at a rate of $10^{\circ} \mathrm{C} / \mathrm{min}$ (hold $10 \mathrm{~min}$ ).

The mean recovery of $m$-terphenyl was $82 \pm 16 \%$ (concentrations were not corrected for \% recovery). Based on replicate extractions and analyses of sediment intervals from the deeper sections of the core, the coefficient of variance for PAH concentrations was $<20 \%$. Since recoveries of naphthalene using this protocol were low (Jautzy et al., 2013), their concentrations have not been included in the results. We report: A) the sum of parent PAHs as $\Sigma \mathrm{PAH}_{\text {parent. }}$ These include the 16 EPA priority PAHs minus naphthalene, plus dibenzothiophene. As we could not differentiate among the isomers of benzofluoranthene, concentrations are reported as benzo $[b / j / k]$ fluoranthene; and $\mathrm{B})$ the sum of the alkylated PAHs as $\Sigma \mathrm{PAH}_{\text {alkyl }}$. These include $\mathrm{C}_{1}-\mathrm{C}_{4}$ fluorenes, $\mathrm{C}_{1}-\mathrm{C}_{4}$ dibenzothiophenes, $\mathrm{C}_{1}-\mathrm{C}_{4}$ phenanthrenes/anthracenes, $\mathrm{C}_{1}-\mathrm{C}_{4}$ fluoranthenes/pyrenes and $C_{1}-C_{4}$ chrysenes/benz $[a$ ]anthracenes. Concentrations of retene (1-methyl-7-isopropyl phenanthrene), a $C_{4}$-phenanthrene commonly used as a marker for softwood combustion (e.g., Ahad et al., 2015), are reported separately. The limits of quantification corresponding to the lowest standard concentration on the calibration curve and converted into ng of compound per gram of sediment (dry weight) ranged between 0.5 and $1.0 \mathrm{ng} \mathrm{g}^{-1}$. PAH concentrations below quantification limits are reported as BQL (Table S1). The concentrations of PAHs in each interval were multiplied by the interval's sediment accumulation rate to calculate $\mathrm{PAH}$ accumulation rates $\left(\mu \mathrm{g} \mathrm{m}^{-2} \mathrm{yr}^{-1}\right)$.

\subsection{Hg analysis}

Total $\mathrm{Hg}$ was analyzed in sediments according to EPA method 7473 with a direct mercury analyzer (DMA-80; Milestone, Sorisole, Italy) which uses thermal decomposition followed by gold amalgamation and atomic absorption spectrophotometry. Certified reference material (marine sediment; MESS-3; $n=5$ ) and duplicate samples $(n=4)$ were analyzed for quality assurance. The mean percent recovery of $\mathrm{Hg}$ from MESS-3 was $106 \%$ and the relative standard deviation was $4 \%$. The mean relative percent difference between duplicate samples was $4 \%$.

\section{Results and discussion}

\subsection{Geochronology}

The activities of ${ }^{210} \mathrm{~Pb},{ }^{137} \mathrm{Cs}$ and ${ }^{226} \mathrm{Ra}$ are plotted against depth in Fig. 3A. The ${ }^{210} \mathrm{~Pb}$ activity decreased with depth, reaching background at approximately $21 \mathrm{~cm}$. The ${ }^{137} \mathrm{Cs}$ peak appeared at a depth of $7-8 \mathrm{~cm}$, which, based on the CRS model constructed with ${ }^{210} \mathrm{~Pb}$ activities (Appleby and Oldfield, 1978), corresponded with the date 1973 at the base of the interval. Although the maximum ${ }^{137} \mathrm{Cs}$ fallout from thermonuclear weapons testing occurred in $1963,{ }^{137} \mathrm{Cs}$ may be vertically redistributed after deposition in lake sediments (Smith et al., 1987; Comans et al., 1989; Davis et al., 1984; Klaminder et al., 2012; Smith et al., 2000), thus explaining the observed "flattened" ${ }^{137}$ Cs profile. A gradual increase in sediment accumulation rate (SAR) in the early part of the record coincided with development in the catchment area (Mitchell and Prepas, 1990); consequently, agricultural inputs may help to explain the trends shown in Fig. 3B. The SAR in Hasse Lake showed a peak during the mid-1960s to early 1970s, followed by a decrease around the late 1970 s to early 1980 s, before increasing toward the top of the core (Fig. 3B). Significant overall up-core increases in SAR over the past century were previously reported in lakes in central and northern Alberta and Saskatchewan (Curtis et al., 2010; Donahue et al., 2006; Laird et al., 2013; Summers et al., 2016) and were attributed to enhanced aquatic primary production caused by climate-induced warming (Summers et al., 2016). In addition to agricultural inputs, therefore, recent warming may have also contributed to the increase in SAR in Hasse Lake. Further discussion on Hasse Lake productivity is provided below in Section 3.2. 

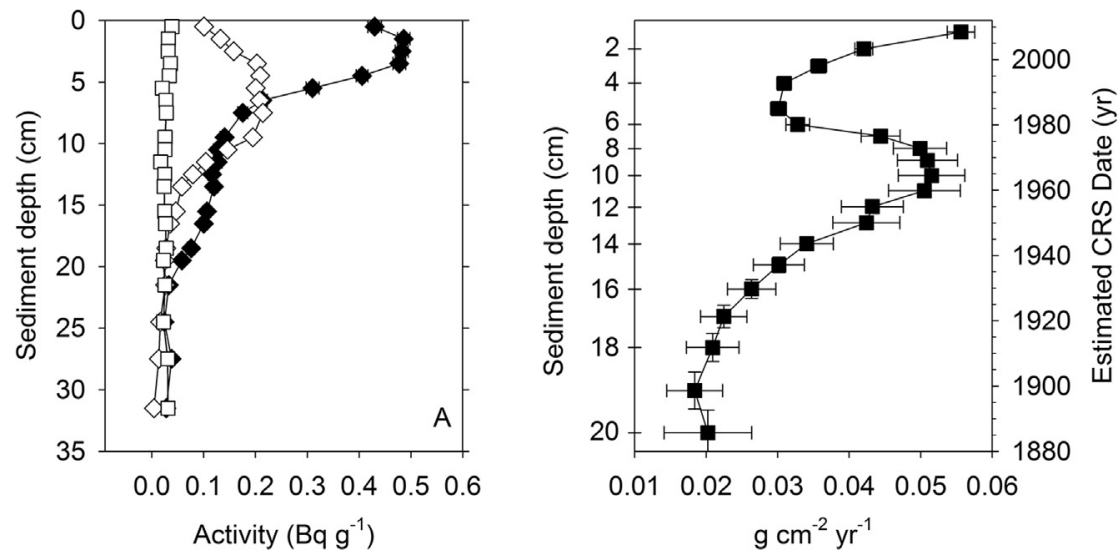

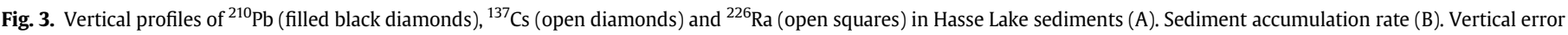
bars in (B) are associated with the estimated CRS dates.

\subsection{Total organic carbon and nitrogen, and sediment stable isotopes}

The TOC content in Hasse Lake sediments ranged from 11.6 to $22.4 \%$ (Fig. 4A). TOC content remained relatively stable from the bottom of the core until $\sim 1933$ followed by an overall decreasing trend to $\sim 1971$. From this horizon, the percentage of TOC increased until 1995 followed by a steep decline to the surface.

The $\mathrm{C} / \mathrm{N}$ ratios (atomic) of Hasse Lake OM ranged between 6.0 and 12.1 (Fig. 4B). There was a slight overall decrease in $\mathrm{C} / \mathrm{N}$ moving up-core to $\sim 2003$ followed by an abrupt decrease to the sediment surface. The range of $\mathrm{C} / \mathrm{N}$ ratios is consistent with that of OM produced from algal material, which tends to have $\mathrm{C} / \mathrm{N}$ ratios between 4 and 10 , rather than vascular plants which tend to produce $\mathrm{C} / \mathrm{N}$ ratios greater than 20 (Meyers, 2003). This suggests that the pool of $\mathrm{OM}$, in the sediments collected from Hasse Lake, was predominately supplied from within-lake primary production.

The temporal trends in $\delta^{13} \mathrm{C}$ and $\delta^{15} \mathrm{~N}$ of bulk organic matter from the two different cores used to evaluate the alignment of different sediment cores in Hasse Lake are reported in the Supporting Information (Fig. S1). Despite a small offset in $\delta^{13} \mathrm{C}$ in the middle of the cores from around 1925 to 1950 that was slightly greater than the analytical uncertainty, the overall trends in $\delta^{13} \mathrm{C}$ over the past century in both cores were very similar, particularly over the past 60 years where almost identical $\delta^{13} \mathrm{C}$ values were measured at the same depth intervals. Such a close agreement in $\delta^{13} \mathrm{C}$ would be highly unlikely if there were significant variations in sedimentation rate over the small area of Hasse Lake where replicate cores were collected. Comparing $\delta{ }^{15} \mathrm{~N}$ between the two cores is more challenging, since the overall range in $\delta^{15} \mathrm{~N}$ was much smaller (1.3 and $2.0 \%$ in the two cores), and there were no clear trends outside the analytical error $(0.4 \%$ ). The slightly larger offset found near the top of the core demonstrates the spatial variability that can occur in lake surface sediment $\delta^{15} \mathrm{~N}$, even in lakes smaller than the current study site (Jones et al., 2004).

The average $\delta^{13} \mathrm{C}$ and $\delta^{15} \mathrm{~N}$ values for the two cores are shown in Fig. 4 (the error bars represent the average deviation for each sediment interval). To better interpret changes in lake productivity over time, average $\delta^{13} \mathrm{C}$ values were corrected for the Suess effect, i.e., the isotopic depletion in atmospheric $\mathrm{CO}_{2}$ caused by the burning of isotopically lighter fossil fuels, following the approach described by Verburg (2007). The Suess effect-corrected $\delta^{13} \mathrm{C}$ signatures of TOC ranged from -30.0 to $-25.3 \%$ (Fig. 4C) and showed a similar overall up-core increase as observed for uncorrected values (Fig. S1). The $\delta^{13} \mathrm{C}$ values were lowest at the bottom of the core and increased near-linearly up to $\sim 1975$ followed by a slight decrease up to $\sim 1989$. From this horizon up to the surface, $\delta^{13} \mathrm{C}$ signatures again increased (Fig. 4C).

Previous studies have used $\delta^{13} \mathrm{C}$ ratios of OM to indicate changes in lake productivity, as primary producers selectively uptake ${ }^{12} \mathrm{CO}_{2}$ leaving behind a dissolved inorganic carbon (DIC) pool which becomes increasingly enriched in ${ }^{13} \mathrm{CO}_{2}$ (Bernasconi et al., 1997;

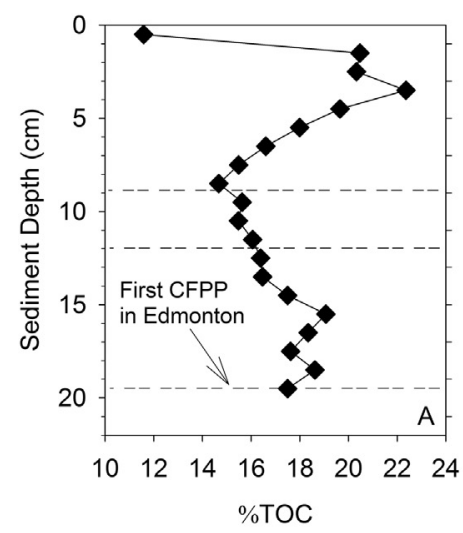

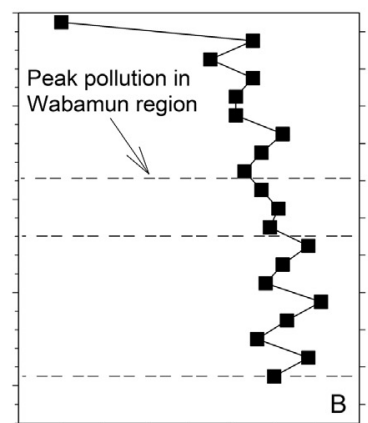

$\begin{array}{llllllllll}5 & 6 & 7 & 8 & 9 & 10 & 11 & 12 & 13\end{array}$ $\mathrm{C} / \mathrm{N}$ atomic
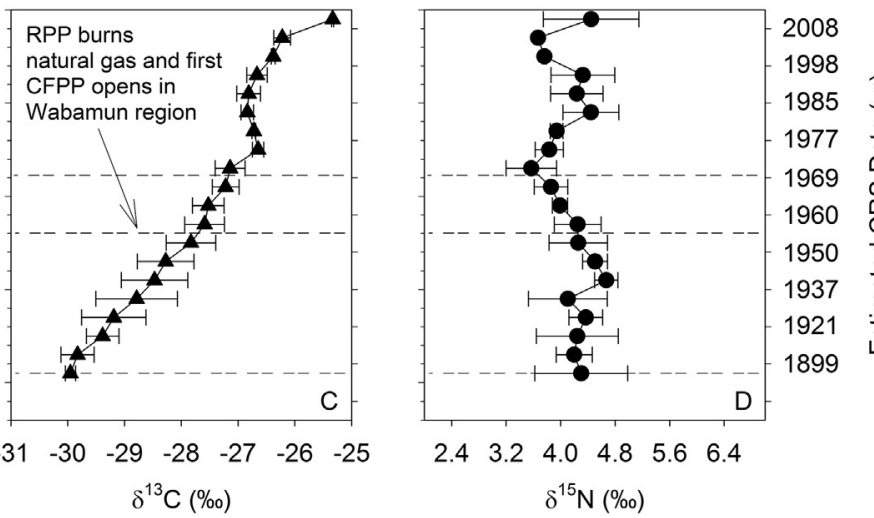

$\begin{array}{llllll}2.4 & 3.2 & 4.0 & 4.8 & 5.6 & 6.4\end{array}$

$\delta^{15} \mathrm{~N}(\%)$

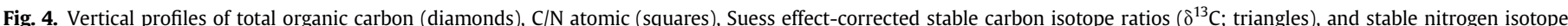

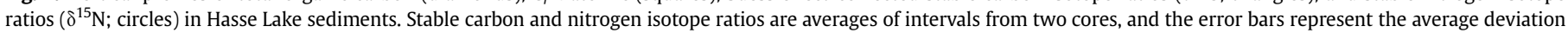
for each sediment interval. RPP $=$ Rossdale power plant; CFPP $=$ coal-fired power plant. 
Hodell and Schelske, 1998; Routh et al., 2004). In other words, periods of high productivity diminish the available ${ }^{12} \mathrm{CO}_{2}$ and ensure that a larger proportion of ${ }^{13} \mathrm{CO}_{2}$ is gradually incorporated into OM (Routh et al., 2004). The overall trend of progressively more positive $\delta^{13} \mathrm{C}$ values up-core in Hasse Lake, in conjunction with decreasing $\mathrm{C} / \mathrm{N}$ ratios, thus points to an increase in primary productivity since the turn of the 20th century, much of it presumably driven by nutrient inputs associated with agricultural land-use in the surrounding watershed. The corresponding overall decrease in \%TOC observed during this period (Fig. 4A) is interpreted as dilution with minerogenic matter due to enhanced soil erosion (Enters et al., 2006; Fisher et al., 2003). As reflected by an increase in SAR over the past several decades (Fig. 3B), climateinduced warming (Summers et al., 2016) may also be contributing to increased productivity in Hasse Lake.

In contrast to $\delta^{13} \mathrm{C}, \delta^{15} \mathrm{~N}$ values in Hasse Lake sediments fell within a much smaller range (3.6-4.7\%o; Fig. 4D). Although there was no overall shift in $\delta^{15} \mathrm{~N}$ to either more positive or negative values, a slight decreasing trend was observed from around 1940 to 1971. However, as mentioned above, most differences in $\delta^{15} \mathrm{~N}$ values fell within the range of analytical uncertainty, and any interpretation of potential impacts caused either directly or indirectly by anthropogenic inputs must take this into account. The difficulty in using sediment $\delta^{15} \mathrm{~N}$ data to assess temporal changes in lake productivity associated with nitrogen deposition in Alberta was previously reported by Curtis et al. (2010).

\subsection{SCPS}

The concentrations of SCPs in Hasse Lake sediments ranged from 250 to $2600 \mathrm{~g} \mathrm{DW}^{-1}$ sediment (Fig. 5A). These concentrations exceed those reported in 12 sediment cores collected from lakes in the Athabasca oil sands region of northern Alberta (Curtis et al., 2010). The concentration of SCPs was lowest at the bottom of the core and rapidly increased to $\sim 1933$, followed by a gradual decrease toward the top of the core. Within this overall decreasing trend a small peak was observed in 1971 . SCP fluxes followed a similar trend to the concentrations, except instead of in $\sim 1933$, the peak accumulation rate occurred in $\sim 1971$ (Fig. 5B). SCPs ranged in size from 4 to $50 \mu \mathrm{m}$ in diameter. The majority of SCPs were greater than $10 \mu \mathrm{m}$ in diameter throughout the core, with the exception of the top sediment layer which contained SCPs between 4 and $10 \mu \mathrm{m}$.

SCPs are unambiguous markers of contamination from hightemperature fossil-fuel combustion (coal and fuel oil, but not gas), as they are not formed during charcoal, wood or biomass combustion (Rose, 2001). Their presence in the deepest sections of the core indicates that fly-ash from anthropogenic fossil-fuel combustion has reached the lake at least as far back as the late 1890s. Meteorological processes may transport airborne contaminants over thousands of kilometers to even remote locations. As a result, SCPs may be detected in sediments which predate local and regional industrial activities, though the vast majority of particles are deposited close to emission sources (Rose, 2001). Possible local and regional sources of SCPs to Hasse Lake include industrial activities in the City of Edmonton and the coal-fired power plants in the Wabamun Region. The first coal-fired power plant in Edmonton, which began operation in 1891, was a possible source of SCPs found in the deepest sections of the core. This power plant would later become the Rossdale plant. Increased demand for electricity during the early 1900s coincided with a 13-fold increase in Rossdale's electrical generation capacity between 1907 and 1914. Power demands intensified in the 1940s in Edmonton, as did concerns over the amount of fly-ash released from the plant. There was no available technology to control fly-ash emissions at the time; however, due to rising coal prices some of the Rossdale boilers were converted to burn natural gas and this helped to curtail particle release. By 1955 all of the boilers of the Rossdale plant were converted to burn natural gas, and the plant operated in this state until it was completely decommissioned in 1998 (Culbertson and Marshall, 2002).

The early part of the SCP accumulation profile corresponds well with the history of coal-combustion in the City of Edmonton. SCP accumulation rates increased rapidly from the bottom of the core and coincided with rapid increases in coal-fired electrical generation in Edmonton. The decline in SCP accumulation rates between the mid-1930s and 1950s coincided with Rossdale's period of transition from coal to natural gas, a fuel-type that does not produce SCPs during combustion. Falling coal prices and everincreasing electricity demands facilitated the opening of the Wabamun Lake coal-fired power plant in 1956, as well as unit additions to the plant over a subsequent 12-year period. The opening of the Sundance plant in 1970 marked a period of peak emissions in the region due to the concurrent operation of the Wabamun and Sundance plants (Sanei, 2005). This period coincided with the rapid increase in SCP accumulation rates from approximately 1957 to a peak in about 1971. This is supported by findings of Sanei et al. (2010) who also noted an enrichment of siliceous fly-ash particles (products of coal combustion) in post-1956 sediments from Wabamun Lake. The decline in SCP accumulation rates in Hasse Lake sediments after 1971 may reflect the effectiveness of particle control technologies (electrostatic precipitators and filter baghouses) implemented during the 1970s, despite the addition of the Keephills and Genesee plants to the region in 1983 and 1989, respectively. The use of these technologies has also been linked to recent declines in SCP accumulation rates to surface sediments in several European lakes (Battarbee et al., 2015; Pla et al., 2009; Rose and Monteith, 2005) and is generally considered an important determinant of recent declines in particle emissions (Rose, 2001).

\subsection{PAH concentrations and accumulation rates}

Despite the variability in Hasse Lake sediment \%TOC values over time (Fig. 4A), similar temporal trends in PAHs were found between TOC-normalized and non-TOC-normalized data. Consequently, only non-TOC-normalized PAH concentrations and fluxes are reported here (Fig. $5 \mathrm{C}-\mathrm{H}$ ). $\Sigma \mathrm{PAH}_{\text {parent }}$ concentrations ranged from 135 to $312 \mathrm{ng} \mathrm{g}^{-1}$ dry weight and showed a decreasing trend from the bottom of the core until $\sim 1957$, followed by a steep increase until $\sim 1971$. $\Sigma \mathrm{PAH}_{\text {parent }}$ again decreased until $\sim 1983$, followed by another increase to $\sim 2001$. $\Sigma \mathrm{PAH}$ parent then decreased slightly to the sediment surface (Fig. $5 \mathrm{C}$ ). The accumulation rates of $\Sigma \mathrm{PAH}_{\text {parent }}$ to Hasse Lake ranged between 44 and $156 \mu \mathrm{g} \mathrm{m}^{-2} \mathrm{yr}^{-1}$ and showed an overall increase from the bottom of the core until a maximum in approximately 1971 . From this horizon there was a rapid decrease to a minimum in 1983 . The $\Sigma \mathrm{PAH}_{\text {parent }}$ accumulation rates then increased to $\sim 2001$, before remaining stable until the sediment surface (Fig. 5D).

$\Sigma \mathrm{PAH}_{\text {alkyl }}$ concentrations, which ranged from 99 to $189 \mathrm{ng} \mathrm{g}^{-1}$ dry weight, showed a similar decreasing trend as parent PAHs from the bottom of the core until $\sim 1962$. Between 1962 and 1995 there was an overall increase, followed by a subsequent decrease to the top three sediment layers measured here (Fig. 5E). The accumulation rates of $\Sigma \mathrm{PAH}_{\text {alkyl }}$ ranged between 25 and $84 \mu \mathrm{g} \mathrm{m}^{-2} \mathrm{yr}^{-1}$ and increased from the bottom of the core until $\sim 1975$. The $\Sigma \mathrm{PAH}_{\mathrm{alkyl}}$ accumulation rates then decreased until 1983 . Accumulation rates remained relatively stable until $\sim 2006$ followed by a sharp increase to the sediment surface (Fig. 5F).

In general, the levels of PAHs in Hasse Lake sediments were low and most fell below the Canadian Council of Ministers of the Environment (CCME) interim sediment quality guidelines (CCME, 

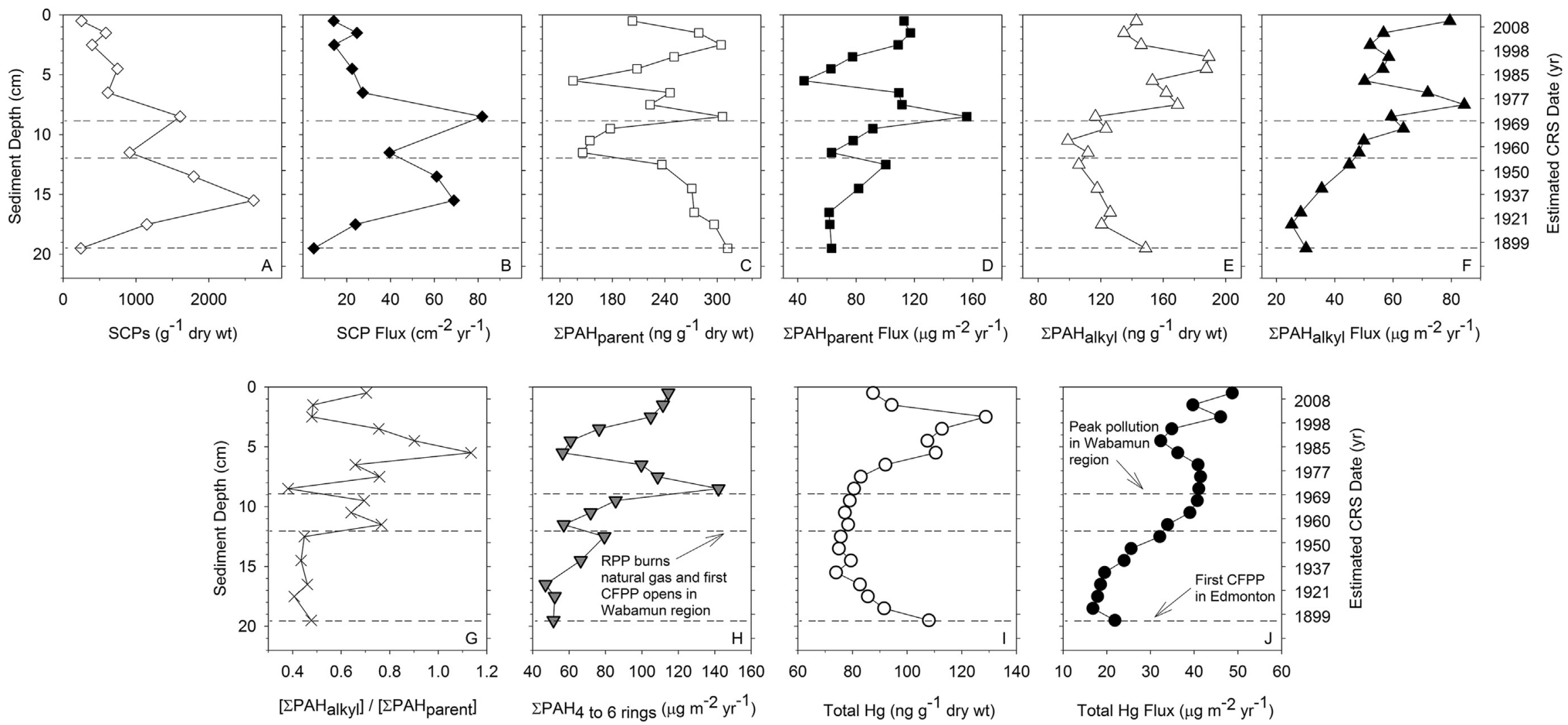

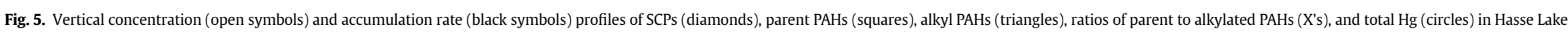
sediments. RPP $=$ Rossdale power plant; CFPP $=$ coal-fired power plant. 
2001). The one exception was pyrene, whose average concentration in the top $0-5 \mathrm{~cm}$ of sediments was approximately $8 \mu \mathrm{g} \mathrm{kg}^{-1}$ higher than CCME guidelines (Supporting Information Table S1). Fluxes of the 16 EPA priority PAHs in the top sediment layers of Hasse Lake also generally fell below those reported for surface sediments of nearby Wabamun Lake, Lac Sainte-Anne, and Pigeon Lake by Donahue et al. (2006), although it should be noted that naphthalene concentrations are not reported here for Hasse Lake. The aforementioned lakes are located to the west of Hasse Lake and were likely more impacted by the coal-fired power plants in the Wabamun Region.

PAHs are ubiquitous in the environment and may be formed through natural and anthropogenic processes, such as incomplete combustion of OM, including both fossil-fuels and modern biomass, as well as via diagenetic processes. Given the possible various sources of PAHs to lake sediments, the interpretation of concentrations and accumulation rates in specific relation to coal-fired power plant inputs should be carried out with caution. With this in mind, the use of SCPs as an unambiguous marker for anthropogenic atmospheric deposition may be useful when inferring sources of PAHs (Martins et al., 2010; Muri et al., 2006; Rose and Rippey, 2002; Fernández et al., 2002; Rose et al., 2004).

The peak accumulation rates for parent PAHs and SCPs ( 1971) coincided with the period of peak emissions reported in the Wabamun region (Sanei, 2005), suggesting that a significant component of PAHs deposited in Hasse Lake sediments during this period were derived from the high-temperature combustion of fossil fuels. As high-temperature combustion also favors the formation of parent rather than alkyl-substituted PAHs (Lima et al., 2005), the relatively low $\Sigma P A H_{\text {alkyl }}$ to $\Sigma P A H_{\text {parent }}$ ratio in approximately 1971 may also indicate the influence of high-temperature combustion processes during this period, as well as during the early to mid-20th century (Fig. 5G). Furthermore, higher molecular weight PAHs, with 4-6 aromatic rings, are often related to combustion processes (Ahad et al., 2015; Yunker et al., 2002), and the accumulation rate of these compounds also peaked at $\sim 1971$ (Fig. 5H). Higher levels of 4-6 ring PAHs (Fig. 5H) and SCPs (Fig. 5B) combined with low $\Sigma \mathrm{PAH}$ alkyl to $\Sigma \mathrm{PAH}_{\text {parent }}$ ratios (Fig. $5 \mathrm{G}$ ) relative to much of the sedimentary record suggest that emissions from Rossdale were an important source of airborne contaminants during the 1920-1950s.

The decreases in PAH accumulation rates during the 1970s may reflect responses to concerns over the environmental impacts of the Wabamun Region power plants. Such responses include improvement in efficiency of coal combustion, as well as implementation of particle control technologies, both of which could have reduced PAH and SCP inputs to Hasse Lake and were known to occur in Alberta after 1970 (Culbertson and Marshall, 2002). The subsequent increases in $\Sigma \mathrm{PAH}_{\text {parent }}$ and $\Sigma \mathrm{PAH}_{\text {alkyl }}$ accumulation rates in Hasse Lake sediments could be due to the addition of the Keephills and Genesee plants in 1983 and 1989, respectively. Importantly, the increases in PAH accumulation rates during this period did not coincide with the SCP accumulation profile. This could indicate that PAHs deposited during this period were linked to regional sources other than the high-temperature combustion of coal, such as motor vehicle or boat exhaust, or that particle arrestor technology is more efficient for larger particles (SCPs), than for smaller ones containing higher levels of PAHs.

The overall trends in SCP (Fig. 5B), parent (Fig. 5D) and alkylated (Fig. 5F) PAH fluxes were similar to the sediment accumulation rates (Fig. 3), implying that peak accumulation rates may have been at least partially due to enhanced erosion of soil enriched in atmospheric pollutants. The small drainage basin for Hasse Lake $\left(7.4 \mathrm{~km}^{2}\right)$, however, infers that only airborne pollutants deposited in the immediate area are preserved in the sediment record, regardless of whether they are deposited directly to the lake or to nearby soils.

\subsection{Hg concentrations and accumulation rates}

Total $\mathrm{Hg}$ ( $\mathrm{THg}$ ) concentrations (Fig. 5I) ranged from 74 to $129 \mathrm{ng} \mathrm{g}^{-1}$ dry weight and decreased from the lowest sediment horizon to approximately 1933 . THg concentrations, which were relatively high in the bottom of the core, showed little variation between $\sim 1933$ and 1971, before peaking in 2001. THg concentrations then decreased from 2001 to the sediment surface. Accumulation rates of $\mathrm{THg}$ ranged from 16.8 to $48.7 \mu \mathrm{g} \mathrm{m}^{-2} \mathrm{yr}^{-1}$ and showed an overall increasing trend from the bottom of the core to $\sim 1975$. A subsequent decrease to $\sim 1989$ was then followed by an increasing trend to the sediment surface (Fig. 5J).

THg concentrations in sediments of nearby Wabamun Lake have been reported in several studies (Donahue et al., 2006; Jackson and Muir, 2012; Sanei, 2005) and are similar to the range of concentrations we report here for Hasse Lake sediments. THg accumulation rates at the bottom of the Hasse Lake core (pre-1910) were between 17 and $22 \mu \mathrm{g} \mathrm{m}^{-2} \mathrm{yr}^{-1}$, which are comparable to many lakes in western North America during this time period, as noted in a recent study by Drevnick et al. (2016). Hasse Lake Hg accumulation rates in more recently deposited sediments have increased by approximately 1.75 -fold relative to pre-1910 rates. According to Drevnick et al. (2016), this rate is similar to increases over the same period for lakes in western North America not directly affected by point sources, but with watersheds that are heavily disturbed by agriculture and/or residential development. These types of watersheds tend to retain $\mathrm{Hg}$ poorly (Domagalski et al., 2016; Drevnick et al., 2016; Shanley and Chalmers, 2012), leading to increasing inputs to lakes, and thus potentially greater accumulation rates in sediments. The total $\mathrm{Hg}$ accumulation rate profile in Hasse Lake sediments is similar to $\mathrm{Hg}$ accumulation rates in nine other lakes (Pigeon, Chip, Sandy, Jackfish, Isle, Brock, Lac LaNonne, Lessard, and Sainte Anne) in the Wabamun region (Donahue et al., 2006; Sanei et al., 2010), indicating that regional changes in $\mathrm{Hg}$ loading have been archived in sediments of multiple lakes across the region (Fig. 6).

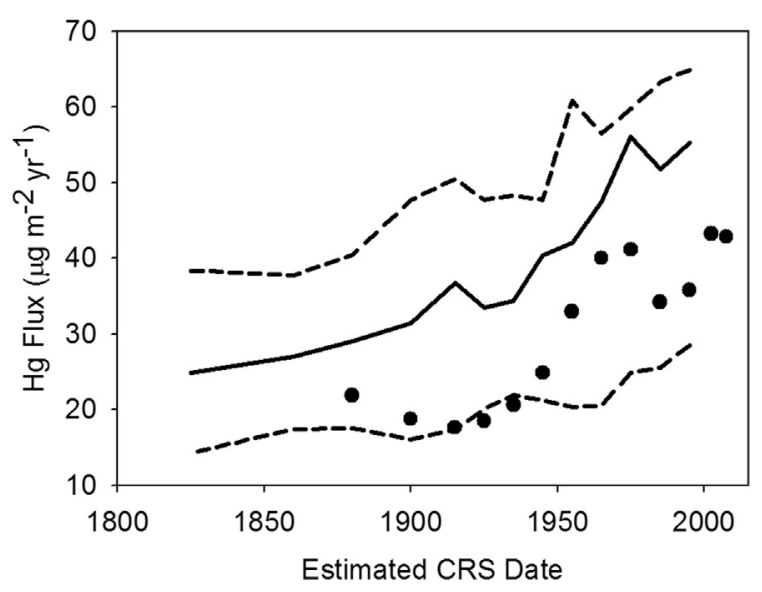

Fig. 6. Total mercury accumulation rates in sediments from nine lakes (Pigeon, Chip, Sandy, Jackfish, Isle, Brock, LaNonne, Lessard, and Sainte Anne) west of Edmonton, Alberta (Donahue et al., 2006; Sanei et al., 2010). The lakes used in the analysis (represented by median, $10^{\text {th }}$ and $90^{\text {th }}$ percentiles; solid and two dashed lines, respectively) are all similar to Hasse Lake (solid circles) in that they are affected by development (agriculture) and atmospheric deposition from local, regional, and global sources of mercury. Wabamun Lake was excluded from the analysis because it is directly impacted by point sources. 


\section{Conclusion}

We measured PAHs, $\mathrm{Hg}$, and SCPs in ${ }^{137} \mathrm{Cs}$ and ${ }^{210} \mathrm{~Pb}$ dated sediments of Hasse Lake, Alberta, in order to evaluate the extent of contamination related to the region's coal-fired power plants. The fly-ash particle record in Hasse Lake sediments indicated a century of atmospheric deposition to the lake. The early SCP record (pre1955) coincided with historical coal combustion in Edmonton at the Rossdale plant, demonstrating this to be a significant regional source of atmospheric pollution. The conversion of this plant to a natural gas-fired power plant resulted in decreased particle emissions in Edmonton (Culbertson and Marshall, 2002), and this appears to be recorded in the sediments of Hasse Lake. The changes in SAR, \%TOC, $\mathrm{C} / \mathrm{N}$ and $\delta^{13} \mathrm{C}$ ratios pointed to agricultural inputs and to an increasingly more productive lake, which may in part be attributed to climate-induced warming. Similar peaks in PAH and SCP accumulation rates in $\sim 1971$ indicated a high-temperature fossil fuel combustion origin for these contaminants. Mercury accumulation rates were comparable to those from other regional lakes but were also similar to other western North American lakes not directly affected by point sources. A noticeable reduction in contaminant inputs to Hasse Lake during the 1970s is attributed in part to technological improvements and stricter emission controls. Post-1980 increases in $\mathrm{Hg}$ and $\mathrm{PAH}$ accumulation rates may be due to the addition of power plants in the Wabamun region, and additional recent sources of PAHs could include motor vehicle and boat exhaust.

This study has provided a historical perspective of over one hundred years of atmospheric emissions associated with coal-fired electricity generation in Central Alberta, shedding light into the effectiveness of environmental regulations and changes in electricity output that have taken place over time. This information is key to evaluating the overall environmental impact of this industry and in determining the role of coal in the world's energy supply.

\section{Notes}

The authors declare no competing financial interest.

\section{Acknowledgements}

Funding for this research was provided by the Earth Science Sector of Natural Resources Canada (CORES Project - Coal \& Oil sands Resources Environmental Sustainability) under the framework of the Environmental Geoscience Program. We thank Anna Smirnoff, Marc Luzincourt, Jade Bergeron, Hooshang Pakdel, Lise Rancourt and René Rodrigue for technical assistance, and Kim Kasperski (CanmetENERGY, Devon, AB) for helping us out with fieldwork logistics. This is Earth Sciences Sector contribution \# 20160127.

\section{Appendix A. Supplementary data}

Supplementary data related to this article can be found at http:// dx.doi.org/10.1016/j.envpol.2017.08.033.

\section{References}

Ahad, J.M., Jautzy, J.J., Cumming, B.F., Das, B., Laird, K.R., Sanei, H., 2015. Sources of polycyclic aromatic hydrocarbons (PAHs) to northwestern Saskatchewan lakes east of the Athabasca oil sands. Org. Geochem. 80, 35-45.

http://agriculture.alberta.ca/acis/alberta-weather-data-viewer.jsp, Alberta Agriculture and Forestry, Alberta Climate Information Service (ACIS).

Appleby, P., Oldfield, F., 1978. The calculation of lead-210 dates assuming a constant rate of supply of unsupported $210 \mathrm{~Pb}$ to the sediment. Catena 5, 1-8.

Appleby, P., Nolan, P., Gifford, D.W., Godfrey, M.J., Oldfield, F., Anderson, N.J., Battarbee, R.W., 1986. 210Pb dating by low background gamma counting.
Hydrobiologia 141, 21-27.

Appleby, P., Richardson, N., Nolan, P., 1992. Self-absorption corrections for well-type germanium detectors. Nucl. Instrum. Methods Phys. Res. Sect. B Beam Interact. Mater. Atoms 71, 228-233.

Battarbee, R.W., Turner, S., Yang, H., Rose, N.L., Smyntek, P.M., Reimer, P.J., Oldfield, F., Jones, V.J., Flower, R.J., Roe, K., 2015. Air pollutant contamination and acidification of surface waters in the North York Moors, UK: multi-proxy evidence from the sediments of a moorland pool. Holocene 25, 226-237.

Bernasconi, S.M., Barbieri, A., Simona, M., 1997. Carbon and nitrogen isotope variations in sedimenting OM in Lake Lugano. Limnol. Oceanogr. 42, 1755-1765.

Boffetta, P., Jourenkova, N., Gustavsson, P., 1997. Cancer risk from occupational and environmental exposure to polycyclic aromatic hydrocarbons. Cancer Causes Control 8, 444-472.

Boström, C.-E., Gerde, P., Hanberg, A., Jernström, B., Johansson, C., Kyrklund, T., Rannug, A., Törnqvist, M., Victorin, K., Westerholm, R., 2002. Cancer risk assessment, indicators, and guidelines for polycyclic aromatic hydrocarbons in the ambient air. Environ. health Perspect. 110, 451.

CCME, 2001. Canadian Council of Ministers of the Environment (CCME), Canadian Sediment Quality Guidelines for the Protection of Aquatic Life. http://st-ts.ccme. ca.

CEC, 2011. Comission for Environmental Cooperation. North American Power Plant Air Emissions, p. 58. http://www.cec.org/.

Colavecchia, M.V., Backus, S.M., Hodson, P.V., Parrott, J.L., 2004. Toxicity of oil sands to early life stages of fathead minnows (Pimephales promelas). Environ. Toxicol. Chem. 23, 1709-1718.

Comans, R.N., Middelburg, J.J., Zonderhuis, J., Woittiez, J.R., Lange, G.J.D., Das, H.A. Weijden, C.H., 1989. Mobilization of radiocaesium in pore water of lake sediments. Nature 339, 367-369.

Culbertson, D., Marshall, H., 2002. Candles to kilowatts: the story of Edmonton's power company. Duval House Publishing, Edmonton.

Curtis, C.J., Flower, R.J., Rose, N., Shilland, J., Simpson, G.L., Turner, S., Yang, H., PlaRabes, S., 2010. Palaeolimnological assessment of lake acidification and environmental change in the Athabasca oil sands region, alberta. J. Limnol. 69 (1), 92-104.

Davis, R.B., Hess, C.T., Norton, S.A., Hanson, D.W., Hoagland, K.D., Anderson, D.S., 1984. $137 \mathrm{CS}$ and $210 \mathrm{~Pb}$ dating of sediments from soft-water lakes in New England (USA) and Scandinavia, a failure of 137 Cs dating. Chem. Geol. 44, $151-185$.

Domagalski, J., Majewski, M.S., Alpers, C.N., Eckley, C.S., Eagles-Smith, C.A. Schenk, L., Wherry, S., 2016. Comparison of Mercury Mass Loading in Streams to Atmospheric Deposition in Watersheds of Western North America: Evidence for Non-atmospheric Mercury Sources. Science of the Total Environment.

Donahue, W., Allen, E., Schindler, D., 2006. Impacts of coal-fired power plants on trace metals and polycyclic aromatic hydrocarbons (PAHs) in lake sediments in central Alberta, Canada. J. Paleolimnol. 35, 111-128.

Drevnick, P.E., Cooke, C.A., Barraza, D., Blais, J.M., Coale, K.H., Cumming, B.F. Curtis, C.J., Das, B., Donahue, W.F., Eagles-Smith, C.A., 2016. Spatiotemporal Patterns of Mercury Accumulation in Lake Sediments of Western North America. Science of the Total Environment.

Eisler, R., 1987. Polycyclic aromatic hydrocarbon hazards to fish, wildlife, and in vertebrates: a synoptic review. U. S. Fish Wildl. Serv. Biol. Rep. 85, 81.

www.energy.alberta.ca/, Electricity Statistics.

Enters, D., Lücke, A., Zolitschka, B., 2006. Effects of land-use change on deposition and composition of organic matter in Frickenhauser See, northern Bavaria, Germany. Sci. Total Environ. 369, 178-187.

Fernández, P., Rose, N.L., Vilanova, R.M., Grimalt, J.O., 2002. Spatial and tempora comparison of polycyclic aromatic hydrocarbons and spheroidal carbonaceous particles in remote European lakes. Water, Air Soil Pollut. Focus 2, 261-274.

Fisher, E., Oldfield, F., Wake, R., Boyle, J., Appleby, P., Wolff, G.A., 2003. Molecular marker records of land use change. Org. Geochem. 34, 105-119.

Hodell, D.A., Schelske, C.L., 1998. Production, sedimentation, and isotopic composition of OM in Lake Ontario. Limnol. Oceanogr. 43, 200-214.

Jackson, T.A., Muir, D.C., 2012. Mass-dependent and mass-independent variations in the isotope composition of mercury in a sediment core from a lake polluted by emissions from the combustion of coal. Sci. Total Environ. 417, 189-203.

Jautzy, J., Ahad, J.M., Gobeil, C., Savard, M.M., 2013. Century-long source apportionment of PAHs in Athabasca oil sands region lakes using diagnostic ratios and compound-specific carbon isotope signatures. Environ. Sci. Technol. 47, 6155-6163.

Jautzy, J.J., Ahad, J.M., Gobeil, C., Smirnoff, A., Barst, B.D., Savard, M.M., 2015. Isotopic evidence for oil sands petroleum coke in the peace-athabasca Delta. Environ. Sci. Technol. 49, 12062-12070.

Jones, R., King, L., Dent, M., Maberly, S., Gibson, C., 2004. Nitrogen stable isotope ratios in surface sediments, epilithon and macrophytes from upland lakes with differing nutrient status. Freshw. Biol. 49, 382-391.

Klaminder, J., Appleby, P., Crook, P., Renberg, I., 2012. Post-deposition diffusion of 137Cs in lake sediment: implications for radiocaesium dating. Sedimentology 59, 2259-2267.

Laird, K.R., Das, B., Kingsbury, M., Moos, M.T., Pla-Rabes, S., Ahad, J.M.E., Wiltse, B. Cumming, B.F., 2013. Paleolimnological assessment of limnological change in 10 lakes from northwest Saskatchewan downwind of the Athabasca oils sands based on analysis of siliceous algae and trace metals in sediment cores Hydrobiologia 720, 55-73.

Lima, A.L.C., Farrington, J.W., Reddy, C.M., 2005. Combustion-derived polycyclic aromatic hydrocarbons in the environment-a review. Environ. Forensics 6 
$109-131$.

Martins, C.C. Bícego, M.C., Rose, N.L., Taniguchi, S., Lourenço, R.A., Figueira, R.C Mahiques, M.M., Montone, R.C., 2010. Historical record of polycyclic aromatic hydrocarbons (PAHs) and spheroidal carbonaceous particles (SCPs) in marine sediment cores from Admiralty Bay, King George Island, Antarctica. Environ. Pollut. 158, 192-200.

Mergler, D., Anderson, H.A., Chan, L.H.M., Mahaffey, K.R., Murray, M., Sakamoto, M., Stern, A.H., 2007. Methylmercury exposure and health effects in humans: a worldwide concern. AMBIO A J. Hum. Environ. 36, 3-11.

Meyers, P.A., 2003. Applications of organic geochemistry to paleolimnological reconstructions: a summary of examples from the Laurentian Great Lakes. Org. Geochem. 34, 261-289.

Mitchell, P., Prepas, E.E., 1990. Atlas of Alberta Lakes. University of Alberta.

Muri, G., Wakeham, S.G., Rose, N.L., 2006. Records of atmospheric delivery of pyrolysis-derived pollutants in recent mountain lake sediments of the Julian Alps (NW Slovenia). Environ. Pollut. 139, 461-468.

Newsted, J.L., Giesy, J.P., 1987. Predictive models for photoinduced acute toxicity of polycyclic aromatic hydrocarbons to Daphnia magna, Strauss(Cladocera, Crustacea). Environ. Toxicol. Chem. 6, 445-461.

Pla, S., Monteith, D., Flower, R., Rose, N., 2009. The recent palaeolimnology of remote Scottish loch with special reference to the relative impacts of regional warming and atmospheric contamination. Freshw. Biol. 54, 505-523.

Rose, N.L., 1994. A note on further refinements to a procedure for the extraction of carbonaceous fly-ash particles from sediments. J. Paleolimnol. 11, 201-204.

Rose, N., 2001. Fly-ash Particles, Tracking Environmental Change Using Lake Sediments. Springer, pp. 319-349.

Rose, N.L., 2008. Quality control in the analysis of lake sediments for spheroidal carbonaceous particles. Limnol. Oceanogr. Methods 6, 172-179.

Rose, N., Monteith, D., 2005. Temporal trends in spheroidal carbonaceous particle deposition derived from annual sediment traps and lake sediment cores an their relationship with non-marine sulphate. Environ. Pollut. 137, 151-163.

Rose, N.L., Rippey, B., 2002. The historical record of PAH, PCB, trace metal and flyash particle deposition at a remote lake in north-west Scotland. Environ. Pollut. 117, 121-132.

Rose, N.L., Rose, C., Boyle, J.F., Appleby, P., 2004. Lake-sediment evidence for loca and remote sources of atmospherically deposited pollutants on Svalbard. J. Paleolimnol. 31, 499-513.

Routh, J., Meyers, P.A., Gustafsson, O., Baskaran, M., Hallberg, R., Schöldström, A., 2004. Sedimentary geochemical record of human-induced environmental changes in the Lake Brunnsviken watershed. Swed. Limnol. Oceanogr. 49,
$1560-1569$

Sanei, H., 2005. Environmental Geochemistry and Petrology of the Recent Sediments from Lakes in the Vicinity of the Coal-fired Power Plants in Central Alberta, Canada. University of Victoria.

Sanei, H., Goodarzi, F., Outridge, P., 2010. Spatial distribution of mercury and other trace elements in recent lake sediments from central Alberta, Canada: an assessment of the regional impact of coal-fired power plants. Int. J. Coal Geol. $82,105-115$.

Scheuhammer, A.M., Meyer, M.W., Sandheinrich, M.B., Murray, M.W., 2007. Effects of environmental methylmercury on the health of wild birds, mammals, and fish. AMBIO A J. Hum. Environ. 36, 12-19.

Schindler, D.W., Dillon, P.J., Schreier, H., 2006. A Review of Anthropogenic Sources of Nitrogen and Their Effects on Canadian Aquatic Ecosystems, Nitrogen Cycling in the Americas: Natural and Anthropogenic Influences and Controls. Springer, pp. 25-44.

Shanley, J.B., Chalmers, A.T., 2012. Streamwater fluxes of total mercury and methylmercury into and out of Lake Champlain. Environ. Pollut. 161, 311-320.

Smith, J.N., Ellis, K.M., Nelson, D.M., 1987. Time-dependent modeling of fallout radionuclide transport in a drainage basin: significance of "slow" erosional and "fast" hydrological components. Chem. Geol. 63, 157-180.

Smith, J., Comans, R., Ireland, D., Nolan, L., Hilton, J., 2000. Experimental and in situ study of radiocaesium transfer across the sediment-water interface and mobility in lake sediments. Appl. Geochem. 15, 833-848.

Summers, J.C., Kurek, J., Kirk, J.L., Muir, D.C., Wang, X., Wiklund, J.A., Cooke, C.A., Evans, M.S., Smol, J.P., 2016. Recent warming, rather than industrial emissions of bioavailable nutrients, is the dominant driver of lake primary production shifts across the Athabasca oil sands region. PloS One 11 e0153987.

TransAlta. “Coal.” Retrieved January 21, 2017, from http://www.transalta.com/ourbusiness/coal.

Verburg, P., 2007. The need to correct for the Suess effect in the application of $\delta 13 C$ in sediment of autotrophic Lake Tanganyika, as a productivity proxy in the Anthropocene. J. Paleolimnol. 37, 591-602.

Yang, H., Rose, N., Boyle, J., Battarbee, R., 2001. Storage and distribution of trace metals and spheroidal carbonaceous particles (SCPs) from atmospheric deposition in the catchment peats of Lochnagar, Scotland. Environ. Pollut. 115, $231-238$.

Yunker, M.B., Macdonald, R.W. Vingarzan, R. Mitchell, R.H., Goyette, D. Sylvestre, S., 2002. PAHs in the Fraser River basin: a critical appraisal of PAH ratios as indicators of PAH source and composition. Org. Geochem. 33, 489-515. 